\title{
The Effect of Quality of Products and Services on Trust and Decision of Customers to Choose Banks (Study at Sampang Bank Rakyat Indonesia Branch)
}

\author{
Bambang Raditya ${ }^{1}$, Meithiana Indrasari ${ }^{2}$, Sri Handini ${ }^{3}$, Susanto Soekiman ${ }^{4}$ \\ \{bambang.raditya.purnomo@unitomo.ac.id ${ }^{1}$, meithiana.indrasari@unitomo.ac.id ${ }^{2}$, \\ sri.handini@unitomo.ac.id $\left.{ }^{3}\right\}$ \\ 1,2,3,4 Fakultas Ekonomi dan Bisnis, Universitas Dr. Soetomo Surabaya, Indonesi
}

\begin{abstract}
This research is directed to analyze the influence of product quality and service on customers' trust and decision in choosing the Sampang BRI bank. The data of this study were collected from 200 customer respondents like the BRI Branch Sampang provided using a questionnaire consisting of open and closed questions. Respondents' answers to closed questions about the variables examined in this study were then analyzed using SEM analysis techniques. (Structural equation modeling) with the AMOS 5 (Analysis of Moment Structure) and SPSS version 20.0 package while the answers to open questions are analyzed qualitatively. The results of the analysis show that the quality of service and product quality have a positive and significant effect on customer confidence in choosing the Sampang BRI bank. And the quality of service and product quality have a positive and significant influence on customers' decisions in choosing the Sampang BRI bank. And trust has a positive and significant influence on customers' decisions in choosing the Sampang BRI bank.
\end{abstract}

Keywords: product quality, service, trust, customer decisions, Structural equation modeling

\section{Introduction}

In the era of globalization when competition in the business sector was getting tougher, companies had to have a defense strategy to defend consumers through the quality of products and services, namely faster delivery time, better service than competitors, and high empathy for consumers to be able to participate in competition. Where the results of these studies indicate that information on products or services affects the reputation and satisfaction of consumers, which in the end reputation and satisfaction will affect consumer loyalty. Highperformance services are services that are able to satisfy customer needs or in other words able to exceed customer expectations. So here the quality of services emphasizes the aspect of customer satisfaction. Quality of service has a close relationship with customer satisfaction. And in turn, customer satisfaction can create customer loyalty and loyalty to companies that distinguish satisfactory service quality.

Service quality is very important in the banking business. Banks are increasingly competing in seizing customer based by relying on the quality of service. Interestingly, even though the quality of service of a bank is considered high quality, its customers are also not necessarily loyal. The best value can make customers satisfied and ultimately customers become loyal. Customer loyalty to the services of a bank is sometimes not always in line with the quality of service of the bank. According to the results of the MarkPlus Insight survey with 
the headline 'Indonesian Brand Loyalty Index (IBLI) 2007, banks that are considered to have a high loyalty index for Saving Accounts are: Bank Central Asia followed by Bank Mandiri, HSBC, UOB Buana, Citibank, BNI, NISP Bank, Bank Ekonomi, ABN Amro and Standard Chartered (Infobank No. 345, December 2007 Edition). According to the Indonesian Brand Loyalty Index (IBLI) 2007, Bank BRI is not included in the 10 banks that have a high loyalty index for saving accounts.

And the researchers tried to examine using the variable consumer confidence as a mediation of the variable quality of products and services to variable customer decisions in choosing a Bank at BRI Branch Sampang. The formulation of the problems in this study are (1) Does the quality of the product support priority preferences in choosing a bank?, (2) Does the service approved compared to priority interests in choosing a bank?, (3) Does the quality of the product preferred compared to the decision in choosing a bank?, (4)Does the service approved compared to priority interests in choosing a bank?, (5) Does trust in decision decisions choose the Bank?

The purpose of this study areto analyze (1) Effect of product quality on customer trust in choosing a bank, (2) Effect of service on customer trust in choosing a bank, (3) Effect of product quality on the customer's decision in choosing a bank, (4) Effect of service on customer decisions in choosing a bank, (5) Effect of trust in the customer's decision in choosing a bank.

\section{Literature review}

\subsection{Product Quality}

Product quality according to Kotler and Armstrong [1] is the ability of a product to show various functions including resilience, reliability, accuracy and ease of use. Customer trust is highly dependent on how the quality of the product offered, but unfortunately in this study noted that there is a lack of attention between product quality and customer trust in service companies. Product performance as perceived by customers influences customer trust. Differentiation into product superiority has the potential to increase consumer confidence.

According to David Garvin in Tjiptono [2], to determine the dimensions of product quality, it can go through eight dimensions as follows:

a. Performance, this is related to the functional aspects of an item and is the main characteristic that customers consider in buying the item.

b. Features, namely performance aspects that are useful for adding basic functions, related to product choices and development.

c. Reliability, things related to the probability or possibility of an item successfully carrying out its function every time used in a certain period of time and under certain conditions.

d. Conformance, this is related to the level of conformity with specifications that have been previously set based on customer desires.

e. Durability, which is a reflection of economic life in the form of a measure of the durability or lifetime of an item.

f. Serviceability, which is a characteristic related to speed, competence, ease, and accuracy in providing services to repair goods.

g. Aesthetics is a subjective characteristic of aesthetic values related to personal considerations and reflections of individual preferences.

h. Perceived quality, consumers do not always have complete information about product attributes. However, consumers usually have information about products indirectly. 


\subsection{Service}

Good service is one of the requirements for success in the company. Service quality is often interpreted as a comparison between expected services and services received in real terms. Tjiptono [2] states that Lewis \& Booms is an expert who first defines service quality as a measure of how well the level of service provided is able to meet customer expectations.

There are two factors that affect the quality of services, namely the expected service and perceived service. Quality must begin with customer needs and end at the customer's perception. This means that the image of good quality is not based on the perspective or perception of the service provider but rather from the customer's point of view or perception. The good and bad quality of service is the responsibility of all parts of the company's organization. Therefore, the quality of services depends on the ability of service providers to meet customer expectations consistently [2].

In one study of service quality by Parasuraman [3] involving 800 customers (divided into four companies) aged 25 years and over, it was concluded that there were five dimensions of service quality, as follows:

a. Tangible, namely the ability of a company to show its existence to external parties. The appearance and ability of reliable facilities and physical infrastructure of the company in the surrounding environment are clear evidence of the services provided by service providers. This includes physical facilities (for example buildings, warehouses, etc.), equipment and equipment used (technology) and the appearance of employees.

b. Reliability, namely the company's ability to provide services in accordance with the promised accurately and reliably. Performance must be in accordance with customer expectations which means timeliness, the same service for all customers without errors, a sympathetic attitude and with high accuracy.

c. Responsiveness, which is a policy to help and provide services that are fast (responsive) and appropriate to customers by delivering clear information. Let consumers wait for negative perceptions of service quality.

d. Guarantee and certainty, namely knowledge, politeness and the ability of company employees to foster trust in customers to the company. This includes several components such as communication, credibility, security, competence (competence) and courtesy.

e. Empathy, which is giving genuine and individual or personal attention given to customers by trying to understand the desires of consumers. Where a company is expected to have an understanding and knowledge of customers, understand customer needs specifically, and have a comfortable operating time for customers.

\subsection{Trust}

According to Mowen and Minor in Sangadji [4] defines consumer trust as all knowledge held by consumers, and all conclusions made by consumers about objects, attributes, and benefits. According to McKnight, Choudury, and Kacmar [5], trust begins before certain parties get to know each other through interactions and transactions.

According to McKnight et al [5] states that there are two dimensions to consumer trust, namely:

a. Trusting Belief is the perception of the party who believes (the consumer) towards the trusted party where the seller has characteristics that will benefit the consumer. There are three elements that build a trusting belief, namely: 
1) Benevolence means how much someone believes in a seller to behave well to consumers. Benevolence is the seller's willingness to serve the interests of consumers.

2) Integrity is how much a person believes in the honesty of the seller to maintain and fulfill the agreement made to the consumer.

3) Competence is a person's belief in the ability of the seller to help consumers do things according to what the customer needs. The essence of competency is the seller's ability to meet consumer needs.

b. Trusting Intention is an intentional thing where someone is ready to depend on other people in a situation, this happens personally and leads directly to others. McKnight et al

[5] state that there are two elements that build trusting intention, namely:

1) Willingness to depend is the willingness of consumers to depend on the seller in the form of acceptance of risks or negative consequences that may occur.

2) Subjective probability of depending is the willingness of consumers to be subjective in the form of providing personal information to sellers, making transactions, and willing to follow suggestions or requests from sellers.

The dimensions of customer trust according to Smith and Barclay cited by Jasfar and Farida[6] consist of:

a. Character, which is related to human nature and behavior.

b. Competency, which is related to expertise and professionalization in delivery.

c. Judgment, which is the result of thinking that distinguishes a choice.

McKnight et al [5] stated that there are factors that can influence consumer confidence, namely:

a. Perceived web vendor reputation. Reputation is an attribute that is given to the seller based on information from other people or sources. Reputation can be important to build a consumer's trust in the seller because consumers do not have personal experience with the seller. Reputation from mouth to the mouth can also be a key to consumer interest. Positive information that is heard by consumers about sellers can reduce the perception of risk and insecurity when transacting with sellers. This can help increase consumer confidence about competency, benevolence, and integrity to the seller.

b. Perceived web site quality, which is the perception of the quality of the site from a virtual store. The appearance of a virtual store can affect the first impression that is formed.

There is a way to build trust through an approach. Such approaches include:

a. Physical Proximity is that companies must be able to build good communication with their customers.

b. Intellectual proximity is a closeness that needs to be applied also so that trust is not only on the surface, but also can reach the mind.

c. Emotional closeness, physical and intellectual closeness do need to be built, but the most important thing is to maintain emotional closeness.

\subsection{Customer Decision}

According to Kotler [7] before deciding to purchase goods or services, consumers will usually go through 5 stages, namely: Problem recognition, Information seeking, Evaluation of alternatives, Buying decisions, and Behavior after purchase. Whereas According to Kotler [1] the stages passed by consumers to reach a buying decision, namely: 
1. Introduction to the Problem. This process occurs when consumers face a problem that is a situation where there is a difference between the desired condition and the actual situation.

2. Information Search. There are two information searches, namely internal search is information obtained from itself such as personal experience and consumer memory and external search is when consumers look for information from their environments such as advertisements, experiences of close friends, and community opinion.

3. Alternative Evaluation. Alternative evaluation is the stage where the consumer evaluates various alternatives and makes the best value judgment to meet the needs.

4. Purchases. Purchases include consumer decisions about what was bought, whether to buy or not when to buy, where to buy, and how to pay.

Post-purchase behavior. After consuming a product or service, consumers will have a sense of satisfaction or dissatisfaction with the product or service they consume. Hypothesis

a. Product quality affects customer confidence in choosing a bank.

b. Services affect customer confidence in choosing a bank.

c. Product quality influences customer decisions in choosing a bank.

d. Services affect the customer's decision in choosing a bank.

e. Trust affects the customer's decision in choosing a bank.

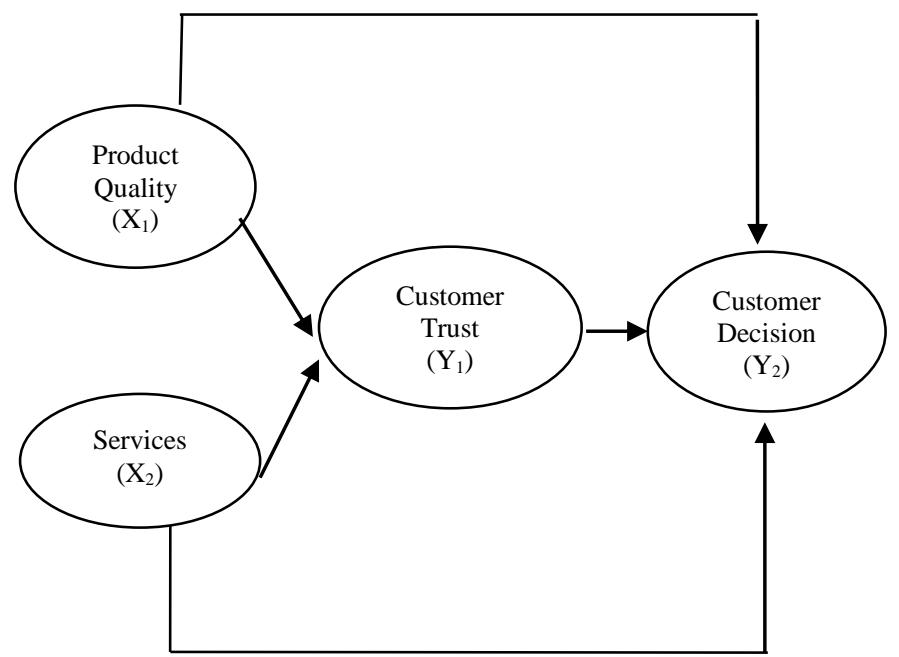

Fig. 1. Conceptual Framework 


\section{METHODS}

\subsection{Types of Research}

This design is an explanatory study, namely research that explains causality between several variables through testing hypotheses [8].

\subsection{Population, Samples, and Sampling Techniques}

The population in this study were 200 customers of Sampang Branch BRI Bank, where sampling was determined by accidental sampling.

\subsection{Data Collection Techniques}

The data collection technique in this study was conducted through questionnaires and the questioner measurement scale of this study using a Likert scale.

\subsection{Operational Definition}

Exogenous Variable $(\mathrm{X})$ consists of:

a. Product Quality $\left(\mathrm{X}_{1}\right)$

is the ability of a product to show various functions including resilience, reliability, accuracy, and ease of use. Furthermore, the variable of product quality is measured according to David Garvin in Tjiptono [2]:

1) Performance $\left(\mathrm{X}_{1.1}\right)$

2) Features $\left(\mathrm{X}_{1.2}\right)$

3) Reliability $\left(\mathrm{X}_{1 \cdot 3}\right)$

4) Conformance $\left(X_{1.4}\right)$

5) Durability $\left(X_{1.5}\right)$

6) Serviceability $\left(\mathrm{X}_{1.6}\right)$

7) Asthetics $\left(\mathrm{X}_{1.7}\right)$

8) Perceived Quality $\left(\mathrm{X}_{1.6}\right)$

b. Service $\left(\mathrm{X}_{2}\right)$

Is a comparison between the services that are expected and the services that are actually received by Lewis \& Booms.

1) Tangible $\left(\mathrm{X}_{2 \cdot 1}\right)$

2) Reliability $\left(\mathrm{X}_{2 \cdot 2}\right)$

3) Responsiveness $\left(\mathrm{X}_{2 \cdot 3}\right)$

4) Assurance $\left(X_{2.4}\right)$

5) Empathy $\left(\mathrm{X}_{2.5}\right)$

Dependent Variable (Y) consists of:

a. Customer Trust $\left(\mathrm{Y}_{1}\right)$

Is the willingness of customers to accept what they are, and hope for good behavior from

BRI banks. Trust factors measured through indicators (McKnight et al [5]) are:

1) The ability to be honest and keep promises $\left(\mathrm{Y}_{1.1}\right)$. It is an attitude as it is and fulfills what has been promised which is shown by the BRI bank.

2) Attention and empathy $\left(Y_{1.2}\right)$. It is a form of concern and also feels what is felt by others shown by the BRI bank.

3) The ability to provide service and satisfaction $\left(\mathrm{Y}_{1.3}\right)$. It is the provision of services from BRI banks which gives satisfaction to other parties. 
b. Customer Decision $\left(\mathrm{Y}_{2}\right)$

It is the customer's process to assess and then choose from various bank alternatives, according to their interests by setting a choice for a particular bank that is considered the best. Customer decision factors are measured through indicators (Kotler, 2017)

1) Introduction to needs $\left(Y_{2.1}\right)$

Is identifying the needs and desires of an unmet customer from BRI bank.

2) Information search $\left(\mathrm{Y}_{2.2}\right)$

It is the collection of various customer information about BRI banks to meet their needs.

3) Alternative Evaluation $\left(\mathrm{Y}_{2.3}\right)$

Is the process of assessing several bank alternatives that are suitable for a customer's needs.

4) Decide $\left(Y_{2.4}\right)$

Is the process of a customer in the selection of a bank.

5) Behavior after deciding $\left(Y_{2.5}\right)$

It is the satisfaction or dissatisfaction of a customer after deciding to choose a BRI bank.

\subsection{Data Analysis Technique}

The analysis technique used in this study is to use Structural Equation Modeling (SEM). SEM is a powerful statistical technique in determining measurement models and structural models based on causality relationships, namely the occurrence of changes in one variable has an impact on the other variable changes. So that the use of SEM in accordance with the purpose of this study is to prove and analyze the influence of exogenous variables (product quality and service) on endogenous variables (customer beliefs and decisions). While the variables in this study are latent variables, so the data analysis uses SEM analysis techniques. (Structural equation modeling) with the AMOS 5 (Analysis of Moment Structure) and SPSS version 20.0 package.

\section{Results and discussion}

\subsection{Research Result}

The model match test shows the conceptual model has been able to explain the empirical conditions studied. The Chi-Square index shows the results of 1.976 with the probability of rejecting $\mathrm{H} 0$ above $5 \%$, which means that the empirical model with the conceptual model tested shows no different. The RMSEA index is below the cut off value of $0.8(0,000)$, AGFI is above $0.8(0.941)$, GFI is above $0.9(0.960)$ as well as TLI $(1,016)$ and CFI $(1,000)$ has exceeded the critical limit of 0.95 so the model is declared fit.

Based on the results of the path coefficient analysis, we get two equation models of this study, namely:

Equation I: $\mathrm{Y} 1=0.193 \mathrm{X} 1+0.204 \mathrm{X} 2$

Equation II: $\mathrm{Y} 2=0.191 \mathrm{X} 1+0.170 \mathrm{X} 2+0.240 \mathrm{Y} 1$

This equation can be seen in figure 2 below. 


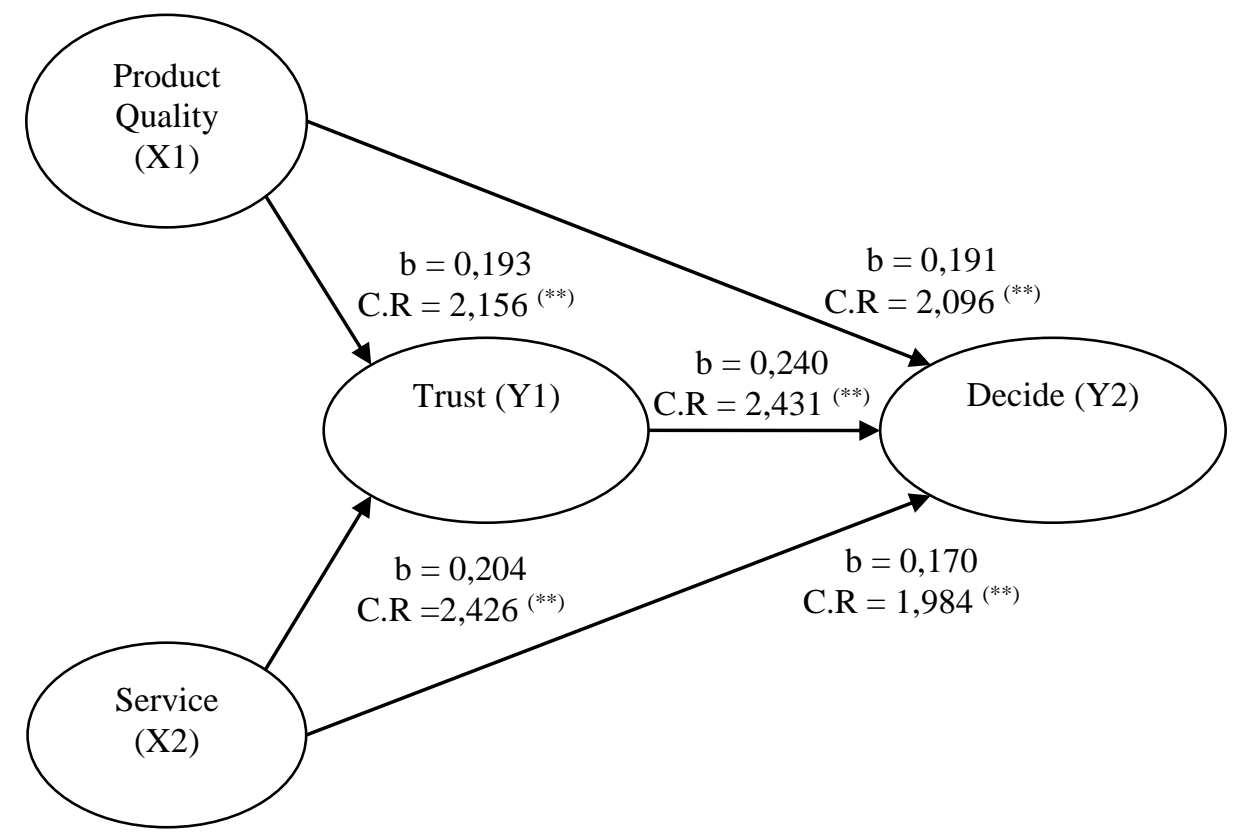

Fig. 2. Path Coefficient Analysis Results

The first equation from the results of the analysis provides an explanation of the relationship between the variables of product quality and service to customer trust in choosing a BRI bank. Customer trust is positively influenced by product quality of 0.193 and service of 0.204. The increase in product quality that is increasingly positive will lead to an increase in trust, as well as improved service quality, customer confidence will also increase by the path coefficient.

The results in the second equation explain the direct effect of the variables on product quality, service, and trust in customer decisions in choosing a BRI bank. The increase in product quality by 1 standard deviation will have an impact on increasing customer decisions by 0.191 as well as vice versa when a decrease in the variable will be followed by a change in the same direction. While the direct influence of the service variable shows a coefficient value of 0.170 and the variable of customer trust is 0.240 .

Table 1. Hypothesis Testing Results

\begin{tabular}{lllrlll}
\hline & & & Estimate & S.E. & C.R. & P \\
\hline Y1 & $<---$ & X1 & 0,193 & 0,090 & 2,156 & 0,031 \\
Y1 & $<---$ & X2 & 0,204 & 0,084 & 2,426 & 0,015 \\
Y2 & $<---$ & X1 & 0,191 & 0,091 & 2,096 & 0,036 \\
Y2 & $<---$ & X2 & 0,170 & 0,086 & 1,984 & 0,047 \\
Y2 & $<---$ & Y1 & 0,240 & 0,099 & 2,431 & 0,015 \\
\hline
\end{tabular}


The first hypothesis (H1) which tests the significance of the direct effect of product quality on customer trust shows a significant effect with a positive path coefficient of 0.193 with a value of C.R. equal to 2.156 and obtained a significance probability (p) of 0.031 which is smaller than the significance level $(\square)$ which is determined as 0.05 . Thus product quality (X1) directly affects trust (Y1), which means that whenever there is an increase in product quality it will increase customer confidence in choosing BRI banks.

The second hypothesis (H2) which tests the significance of the direct effect between customer service and trust shows a significant effect with a positive path coefficient of 0.204 with a value of C.R. amounting to 2.426 and obtained a significance probability (p) of 0.015 which is smaller than the significance level $(\square)$ determined at 0.05 . Thus service (X2) directly influences trust (Y1), which means that whenever there is an increase in service, it will increase trust.

The third hypothesis (H3) which tests the significance of the direct effect between product quality on customer decisions shows a significant effect with a positive path coefficient of 0.191 with a value of C.R. equal to 2.096 and obtained a significance probability (p) of 0.036 which is smaller than the significance level $(\square)$ which is determined as 0.05 . Thus product quality (X1) directly influences customer decisions (Y2), which means that whenever there is an increase in product quality, it will increase customer decisions in choosing BRI banks.

The fourth hypothesis (H4) which tests the significance of the direct effect between servitude on customer decisions shows a significant effect with a positive path coefficient of 0.170 with a value of C.R. equal to 1.984 and obtained a significance probability (p) of 0.047 which is smaller than the significance level $(\square)$ which is determined as 0.05 . Thus service (X2) directly affects the customer's decision (Y2), which means that whenever there is an increase in service, it will increase the customer's decision in choosing a BRI bank.

The fifth hypothesis (H5) which tests the significance of the direct effect between trust in customer decisions shows a significant effect with a positive path coefficient of 0.240 with a value of C.R. amounting to 2.431 and obtained a significance probability (p) of 0.015 which is smaller than the significance level $(\square)$ which is determined at 0.05 . Thus customer trust (Y1) directly influences the customer's decision (Y2), which means that whenever there is an increase in customer confidence, it will increase the customer's decision in choosing a BRI bank.

\subsection{Discussion}

The results of the analysis show that there is an influence of product quality on customer trust in choosing BRI banks. This shows that the quality of the products embedded in the BRI bank Sampang Branch will be able to give customers confidence in choosing the bank. This is in line with Sumarwan [9] who explained that product quality is all values, thoughts, symbols, which affect a person's behavior, attitudes, beliefs, and habits.

The results of the analysis show that there is an influence of trust on customer trust. This shows that the better the conditions of the services arising from within the customer, the higher his confidence in choosing a BRI bank.

The results of the data analysis conducted also found that product quality had a significant and positive effect on the decision to choose BRI banks. This shows that product quality can determine the extent of the customer's decision in choosing a BRI bank, in line with this it can be explained that product quality is the most fundamental cause of one's desires and behavior. According to Kotler [1], the first factor that influences purchasing behavior is the factor of product quality. Product quality factors are determinants of the most 
basic desires and behaviors to obtain values, perceptions, preferences, and behaviors from other important institutions. Product quality factors have the most extensive influence on consumer behavior. Product quality is the most fundamental cause of one's desires and behavior.

Based on the results of the analysis also found a significant and positive influence on the customer's decision to choose BRI bank. This is in line with the opinion of Kotler (2005) which explains that the insurance factor is one of the factors that arise from within the consumer which greatly influences the purchasing decision. According to Kotler (2005), the choice of one's purchase is influenced by four main service factors, namely motivation, perception, learning, and beliefs and attitudes.

Consumer behavior can provide an explanation of what consumers need, the reason consumers decide to make a purchase, and what factors influence consumers in making a decision to make a purchase. One of the factors that influence consumers in deciding to make a purchase is customer service which consists of motivation, perception, learning, beliefs, and attitudes.

In humans, the influence of the inherent factors attached to each individual, such as motivation, learning, perception, trust, and attitude will react to external input and influence the introduction of needs, information seeking before buying and evaluating various alternatives. The experience that can be obtained from evaluating alternatives will ultimately affect all elements of the factors of service [10].

This result is in line with the results of the study by Fredereca and Chairy [11] which revealed that consumer purchasing decisions are one of them influenced by consumer service factors.

In testing the last hypothesis proves that trust has a significant and positive effect on customer decisions in choosing a BRI bank. This shows that the better the trust, the stronger the purchasing decision made in this case the decision to choose BRI bank. This is in line with Bilondatu [12] who found that trust influences purchasing decisions.

\section{Conclusions and recommendations}

\subsection{Conclusions}

Product quality has a significant direct effect on customer trust in choosing the Sampang BRI bank. Celebration has a significant direct effect on customer trust in choosing the Sampang BRI bank. Product quality has a significant direct effect on customer decisions in choosing the Sampang BRI bank. Celebration has a significant direct effect on customer decisions in choosing the Sampang BRI bank. Trust has a significant direct effect on customer decisions in choosing the Sampang BRI bank.

\subsection{Recommendations}

It is expected that the BRI bank of the Sampang Branch. can increase customer trust, for example through a complete explanation of the advantages of BRI banks compared to other banks. It is hoped that the Sampang BRI bank can increase public opinion that BRI banks can compete with other favorite banks. 


\section{References}

[1] P. Kotler, Marketing Management. Elevent Edition. New Jersey: Prentice Hall, Inc, 2005.

[2] F. Tjiptono and G. Chandra, Pemasaran Strategik Edisi 2, 2nd ed. Yogyakarta: Andi, 2012.

[3] A. Parasuraman, V. A. Zeithaml, and L. Berry, "A. Conceptual Model of Service Quality and Its Implications for Future Research," J. Mark., vol. 49, pp. 41-50, 1985.

[4] E. M. Sangadji and Sopiah, Perilaku Konsumen, 1st ed. Yogyakarta: Penerbit Andi, 2013.

[5] D. H. Mcknight, V. Choudury., and C. J. Kacmar, "Developing And Validating Trust Measure for E-Commerce: An Integrative Typology," Informatin Syst. Res., vol. 13, no. 3, pp. 334-359, 2002.

[6] Jasfar and Farida, "Pentingnya Kualitas Pelayanan Dalam Membangun Kepercayaan Pelanggan dan Keputusan Pembelian," J. Manaj. dan Pemasar. Jasa, vol. 6, no. 1, pp. 57, 2005.

[7] P. Kotler and K. L. Keller, Manajemen Pemasaran, Jilid 1 Edisi Kedua Belas, Terjemahan Bob Sabran. Jakarta: Indeks, 2007.

[8] Sugiyono, Metode Penelitian Kombinasi, Cetakan ke. Bandung: Alfabeta, 2016.

[9] U. Sumarwan, Perilaku Konsumen:Teoridan Penerapannya dalam Pemasaran, Cetakan Ke. Bogor: Ghalia Indonesia, 2003.

[10] B. T. Widjaja, Lifestyle Marketing: Paradigma baru pemasaran bisnis jasa. Jakarta: Gramedia Pustaka Utama, 2009.

[11] G. B. Fredereca and Chairy, "Pengaruh Pelayaan konsumen terhadap keputusan pembelian kembali Smartphone Blackberry," J. Manaj. Teor. dan Terap., vol. 3, no. 2, 2010.

[12] M. R. Bilondatu, "Motivasi, Persepsi, dan Kepercayaan Pengaruhnya Terhadap Keputusan Pembelian Konsumen Pada Sepeda Motor Yamaha di Minahasa," J. EMBA, vol. 1, no. 3, pp. 710-720, 2013. 